\title{
Multifactor Evaluation Process for the Determination of Aid Restoration Home
}

\author{
Ahmad Jazuli ${ }^{1}$, Mukhamad Nurkamid ${ }^{2}$, Muhammad Malik Hakim ${ }^{3}$ \\ \{ahmad.jazuli@umk.ac.id'1 , muhammad.nurkamid@umk.ac.id², malik.hakim@umk.ac.id ${ }^{3}$ \} \\ Informatics Engineering Department, Universitas Muria Kudus, Gondangmanis PO BOX 53 Bae \\ Kudus $^{123}$
}

\begin{abstract}
Needs a clean, livable home complete with adequate infrastructure facilities to become the right of every citizen, especially the allocation of funds from the Center to the area more than activities for institution, but the real fact is that many citizens especially in villages still do not have place of residence which can be said to be livable. The authors to build Decision Support Systems to determine the model of granting relief to the residents who will serve as objects in the determination of the grant Restoration House is not Livable in the village Karanganyar Regency. The method used is a Multifactor Evaluation Process method which uses the collective approach of the decision-making process. The resulting system provides a choice of alternatives in determining recommendations help restore home is not livable. So the effort of realizing a livable village neighborhood that became the right of every citizen actually being realized.
\end{abstract}

Keyword: multifactor evaluation processes, DSS, restoration home.

\section{Introduction}

Hope to have a decent home, clean and have adequate infrastructure is always yearning to every citizen. The idea to manifest a decent home into a government program initiated and dealt specifically in order to help the acceleration of the development of the province through regional empowerment respectively. The various needs of the home are not livable in Indonesia still had a large enough. This can be seen in some areas such as distribution in Central Java there were 3,715 houses is not livable in Central Java that will be fix. Repair aid restoration home focused in 15 counties categories red zone or high levels of poorness. Of whom are Wonosobo Regency, Kebumen, Brebes, Rembang, Purbalingga, Banjarnegara, Banyumas, Pemalang, Demak, Sragen, Klaten, Cilacap, Purworejo, Grobogan, and Blora [1]

The Head of the Regional Development and Planning Board of Central Java Province, said Urip Sihabudin, repair aid restoration home is one attempt to address the question of the intenvention of poverty. Vice Regent of Semarang Nugraha Ngesti says, there are tens of thousands of homes are not habitable in the earth in harmony. Semarang district targeting there are 2000 aid restoration home renovated each year[2]

Domain selection problem house is not livable as a sample of the research is the fact that the needs of the citizens of livable homes especially in areas still is very large. So in this case related government should immediately conduct efforts so that the welfare of communities increased. Decision Support System (DSS) was made as an alternative to systems that can

ICCSET 2018, October 25-26, Kudus, Indonesia

Copyright (c) 2018 EAI

DOI 10.4108/eai.24-10-2018.2280509 
assist in making a decision to help restore the House is not livable. Restoration assistance program for home is not livable is using the method of multifactor evaluation process (MFEP). The criteria needed in this system that is the status of the homeowner, the status of the House, the walls of the House, roof, building and revenue. In the method of decision making is based on MFEP on granting of subjective considerations and objective against the factors considered important. The consideration in the form of granting the weighting (weighting system) for multifactor involved and considered important. A decision support system in the wake of expecting to be used to help the Government of the village of Rembang Cangkring Demak in serving citizens, especially related data service citizens who deserve help to get home that needs livable.

Several studies related to decision support systems using the multifactor evaluation process method are one of the researches from Risya and Heru (2015) with the title "Supporting System for Decision on Selection of New Student Candidates at SMK 2 Sragen with Multifactor Evaluation Process (MFEP) Method". The results of the study tell of the use of a support system for the decision to select new students at SMKN 2 Sragen, Central Java[3].

Another some research Pratiwi (2014) with the title Decision Support System Determination Of Achievement Employees Using Multifactor Evaluation Process Method. The result of research is decision support system application use implementation for the selection of outstanding employees [4].

Some research related to the theme of the house is not livable had many previous researchers do, including on research of Danik Kusumawardhani (2014) with the title of "The Decision Support System Recipient Habitable Home With Using the Weighted Product Method (WP)". On the study produced an application that can determine the population who actually is considered eligible to get help home livable village Pacinan, Balerejo, Madiun, East Java[5].

Another research is Sri Wahyuni Priyanti, et all (2016) with the title "Application of Multifactor Evaluation Process (MFEP) for Selection of Contractors in Road Semisation Projects (Case Study: Procurement Service Unit of Kutai Kartanegara Regency". The research results provide an alternative choice in determining the selection of the contractor on project semenisasi the way for easier file selecting participants in the auction[6]

Other research from Yusuf Maulana (2015) with the title of "The Decision Support System (DSS) for Selection Unworthy House Fund Assistance Web Base platform in District of Kudus City with Topsis Method". Research results are applications that can provide assistance in selecting appropriate decision-making assistance fund house is not livable web based on a district of Kudus City [7]. Natividade, et all (2007) with the title "A multicriteria Decision Support System for Housing Evaluation", says the DSS enables the result to be visualised on a map to housing evaluation involves the analytical and systemic determination of all the factors influencing the value of a property, supported in clear principles and using welldefined criteria[8]. Even the decision support system can be used as a center for clinical information systems that doctors can use to provide the best care services to patients by the name of clinical decision support (CDS)[9]. The optimal decision making strategies are often precisely defined and relatively simple, thus they constrain the parameters of the models of neural decision circuit. Thereby maximizing the speed and accuracy of choices[10].

On the Decision Support System (DSS) house is not livable in progress during this process the calculations are still carried out manually and less effective and efficient. Because it was feared the lack of inaccuracies and errors occurring in the process of selecting appropriate home residents who will receive assistance or done restoration. This decision 
support system is an application that can be used to help the Government of the present village, especially the village of Karanganyar Regency Subdistrict of Cangkring Rembang, Demak in selecting aid restoration house is not livable every citizen. This often happens in the implementation process of selection that are not right on target because the Government could not give the village a complete report therefore needed application that can selection so that efficient performance.

The criteria used in this system is the home ownership status, the status of the House, the walls of the House, the floor of the House, the roof, the roof, the building and the family income. Decision support system was developed with multiuser. Use application-based multiuser allows many people can access the system in. Some users of these systems include admin on duty as well as operators, citizens for seeing the results and data are selected and the village chief as report data. Administrator can entry of data will be a poor residents in the village of Rembang Cangkring that will be processed by using the method of Multifactor Evaluation Process (MFEP). Decision Support System (DSS) to restore the house is not livable developed web based software with SQL Server database ASP.Net 2016. Design the design of the program is a sketch program in general in view of the technical structure of the data. The data structure contains various information needs complete data relationships and it's boundaries. On this research data is stored using unstructured model approach. Design tables that became the needs at home does not restore program DSS livable comprises seven tables. The tables include: population table, table of alternative criteria, subcriteria table, admin table, crips table and spk table.

\section{Research Method}

This research method uses:

a. Study of literatur

Literature studies were obtained from books, articles, journals related to the theme of Decision Support Systems (DSS).

b. Data collection technique

The source of data collection in this study was obtained from Cangkring Rembang Village, Karanganyar District, Demak Regency, Central Java Indonesia.

c. Software development technique

Software development tehniques use approaches the decision making process (procedure). The decision making process consist of seven activities :create constructive a constuctive environment, generate potential solution,evaluating alternatives, chose the best alternative, check your decision, communicate your decision and move to action[11]. Another references the decision making process is spread out in three stages: defining (defining the problem, identifying and limiting the factor, develoment of potential solution), identifying (analysis of the alternative, selecting the alternative) and development (implementing the decision, establishing a control and evaluation system) and seven steps[12].

d. Research framework

The research framework is used to help researchers formulate solutions and facilitate design in making programs (figure 1). Research framework (Also call : research computational modelling) an instructional model for computational modelling, based on a methodology commonly described in the mathematical modelling literature[13] . 


\section{Problems: \\ 1 So far there is no system to determine the restoration of uninhabitable homes \\ 2 Aid selection still uses conventional methods, with elements of closeness village officials}

The Decision Support System (DSS) for the determination of the restoration of the house is not livable in Cangkringrembang Village, Subdistrict Karanganyar, Demak, Central Java

\section{』}

Methodology approach:

Multifactor Evaluation Process (MFEP)

a. Determine the criteria

b.Determine the weights

c. Calculate the criteria and weights for producing top rated as a determinant
Result research:

The Decision Support System (DSS) for the determination of the restoration of the house is not livable in Cangkringrembang Village, Subdistrict Karanganyar, Demak, Central Java

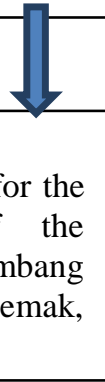

System User:

a. Village head

b. Community and

c. Village officer

Fig. 1. Research framework.

\section{Result and Descussion}

The Decision Support System (DSS) for the determination of the restoration of the house is not livable in Cangkringrembang village, Subdistrict Karanganyar, Demak, Central Java develop using an approach relational model. The relational model in the implementation of the database uses tables. With the relational model, high-quality data relationship quality, which can be used for various purposes, sharing knowledge so that it can be used by anyone who needs data quickly [14].

a) Design tabel

The Decision Support System (DSS) for the determination of the restoration of the house is not livable in Cangkringrembang Village, Subdistrict Karanganyar, Demak, Central Java the research here is to design the database and all the possibilities of the required tables. In the whole database table has a relationship with one another to produce information systems. This research used a database MS SQL Server version 2017 with the programming languages visual studio 2017 (ASP.net). In this accreditation assessment system needed some tables to store its. The tables include: The population table is used to store the entire identity data villagers Cangkring Rembang, Demak. 
Table 1. Alternative Table in Decision Support System for the determination of the restoration of the House is not livable.

\begin{tabular}{llll}
\hline Attribute name & Type & Size & Description \\
\hline Kdalternatif(PK) & Char & 3 & Alternative code \\
Nmalternatif & nvarchar & Max & Alternative name \\
Keterangan & nvarchar & Max & Alternative Description \\
Skor & Numeric & - & Alternative Value \\
Sort & Numeric & - & Rank \\
\hline
\end{tabular}

Alternative table is a table used to record an alternative system of decision, population which includes home owners, the status of the house, the walls of the house floor, roof, building area and earning citizens.

Table 2. Criteria table.

\begin{tabular}{llll}
\hline Attribute name & Type & Size & Description \\
\hline Kdkriteria(PK) & Char & 3 & Criteria code \\
Nmkriteria & Nvarchar & Max & Criteria of name \\
Bobot & Double & - & Criteria weight \\
\hline
\end{tabular}

Table of criteria used to take down the description of each existing criteria include, home ownership = jamkesmas, permanent residents, sword, title = contract, credit banking, the wall = brick, brick making, bamboo, home floor $=$ ground, plastering , ceramic, roof tile $=$ tile, bamboo usuk usuk wood, built-up = type 21 , type 36,45 type, income $=$ father, fathers and mothers, fathers, mothers and children. Key/primary key (PK) in the table of criteria is Kdkriteria.

b) Using Program with Flowchart

The working principle of the program is a Decision Support System (DSS) to restore the House is not livable in the village Cangkring Rembang Karanganyar Regency is by filling/complete all criteria of the existing residents. The criteria includes a number of things, that is, home ownership status, the status of the house, the walls of the house, floor, roof, building and revenue. After the data criteria filled then the next the system will display the data of each subcriteria. Data subcriteria is a detailed description of each criterion. This means that with subkriteria shows every citizen has a different level of social status (figure 2). 


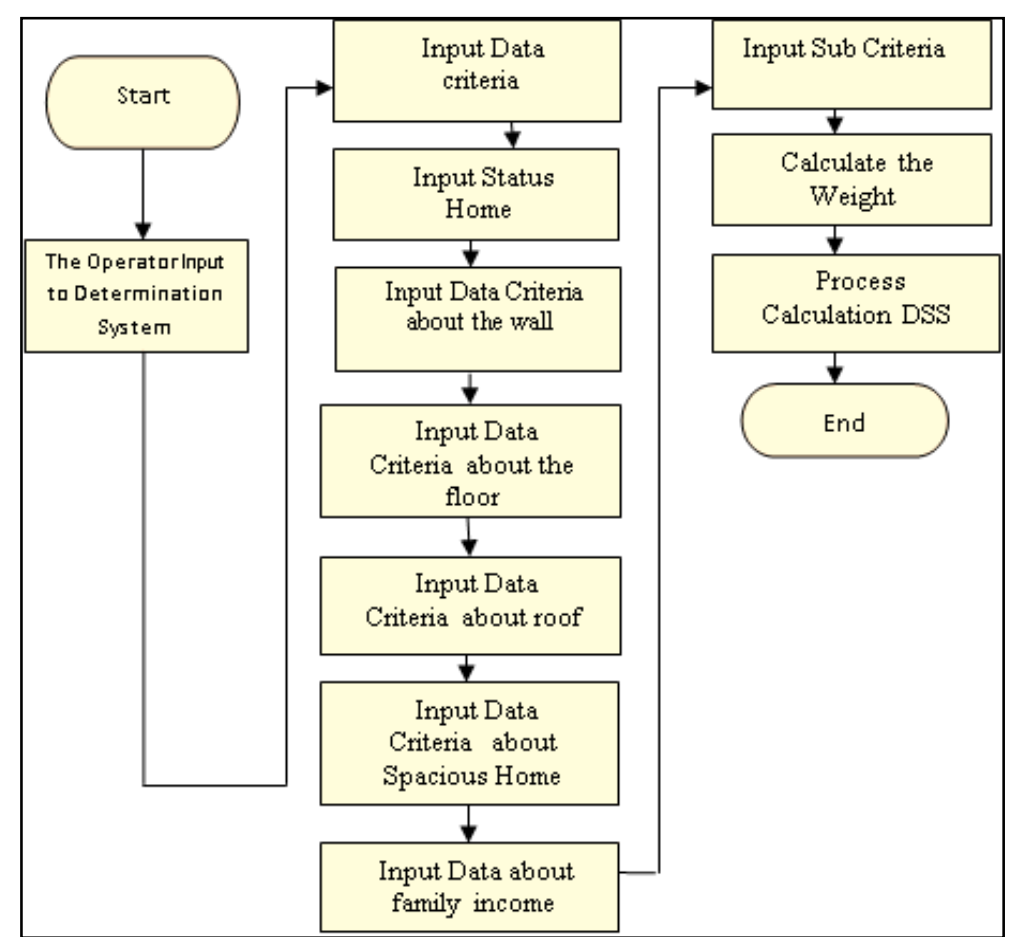

Fig. 2. Flowchart of determination of aid restoration home.

c) Implementation

After the data has sub criteria come next then the process is determining the value of the crips. The value of the crips is a value to determine the weighting of pre-set criteria. Weighting value of the crips started 2 up to 10. After all (crips) is calculated and then the system will calculate the total weighting factor, where the total number of values of the weighting factor is equal to one (1) with the details for the home owners criteria $=0.04$; the status of the house $=0.08$, house wall $=0.20$, floor $=0.16$, roof $=0.18$, building area $=0.12$, earnings $=0.22$. Furthermore, the results of calculation of the weighting factor are multiplied by the weight of the menu of the respective value of the crips. The result of the multiplication is aggregated with all of the criteria so a witch the value of decision support system. After performing next, decision suport system values sort by highest value. From the results of testing eight citizens who are entitled to get help was the brother of the name is JUMADI with results of final value decision support system (figure 3). 


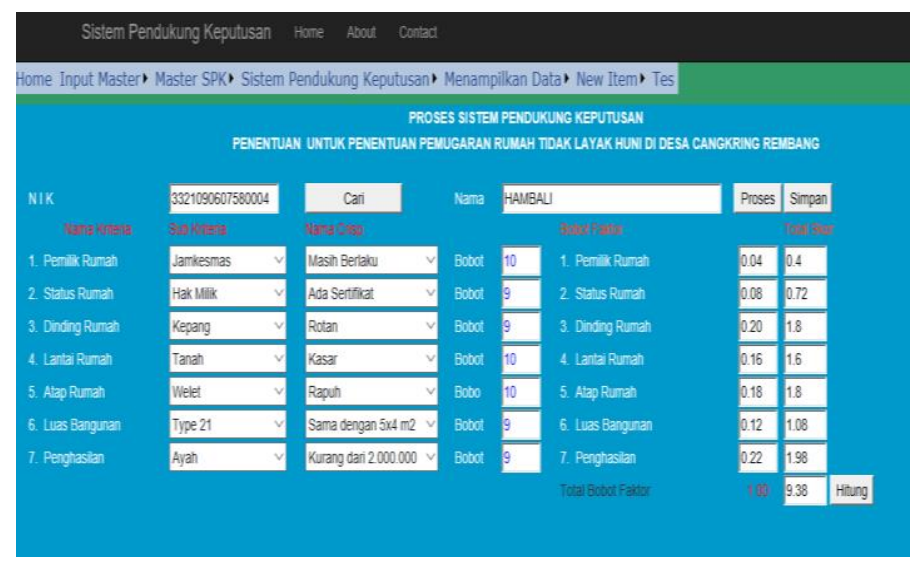

Fig. 3. Decision Making Process (Multifactor Evaluation Process).

Multifactor Evaluation Process (MFEP) is a decision-making model that uses the collective approach of the decision-taking process. The steps in decision with model MFEP are: (1) Determining factors and weighting factors which total weighting must be equal to one. (2) fill in the values for each of the factors that influence in the decision making of data-the data to be processed, the value that you enter in the decision-making process, the value entered in the decision making process is the value objective. (3) the process of calculating weight evaluation, which is the process of calculation of the weighting between the weight factor and factor evaluation with a summation of the entire results weight evaluation to obtain a total result evaluation. Application besides decision support system used by operators of the village also made possible can be used by the village chief as the system user. The village head can login with the username and password that have been created by the admin. The functionality that can be owned by the village head is able to see all the reports the results of the assessment decision support system from the highest score to the lowest value score.

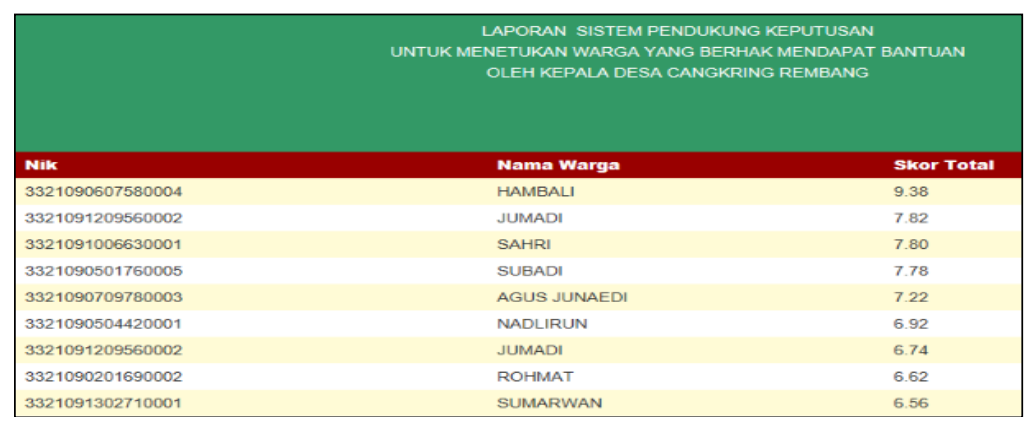

Fig. 4. The Result Making Process (Multifactor Evaluation Process).

d) Program Testing

The last stage of software development is evaluation. The last stage of software development is evaluation. The testing technique in this study was carried out using 
black box testing method. Black box testing as an alternative to white box testing is used to find the errors on the system. Possible errors in the black box testing are: 1 . The wrong functions, 2. Interface error, 3. Error data structures and database access, 4. Performances and errors, 5. Error initializations and terminations. Another definition form black box testing is functional testing. Functional testing according to Nidra \& Srinivas (2012) is case functional testing base on the requirement or design spesification of software entity under test [15].

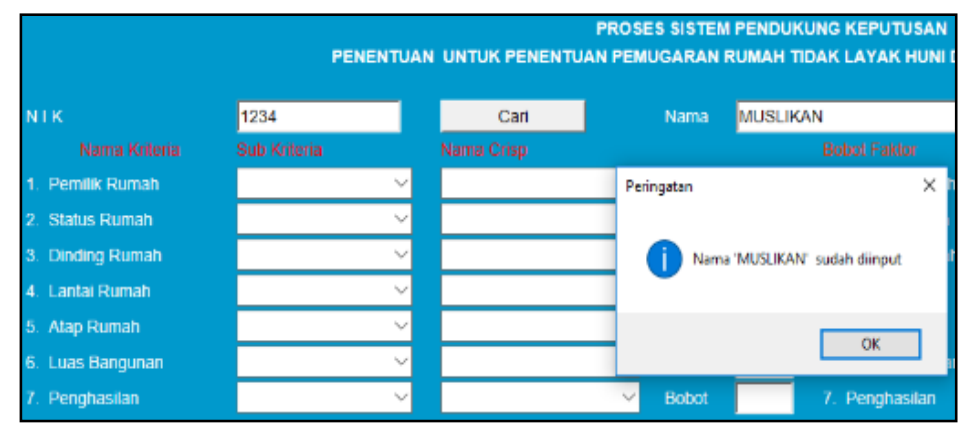

Fig. 5. Validating Process Example.

\section{Conclusion}

The conclusion of this study is

a. The application of a Decision Support System (DSS) which can be used to help the Government of the present village, especially the Cangkring Rembang village, Karanganyar subdistrict, Demak Regency in selecting aid restoration house is not livable every citizen.

b. Decision Support System applications developed using the approach of some of the criteria, namely: home ownership status, the status of the house, the walls of the house, status of the roof, the floor of the house, the status of the building area and income status.

c. Application developed based multiuser, making the implementation of restoration can be run in accountable and transparent, because it involves the whole elements of existing community (residents of Cangkringrembang, the village head and peoples) to access a decision support system.

\section{References}

[1] Tribun-Jateng, 'Tahun ini 3.715 Rumah Tidak Layak Huni di Jateng akan diperbaiki, Anggaran 10 Juta per Unit', 2016.

[2] Tribun-Jateng, 'Ada Puluhan Ribu Rumah Tak Layak Huni di Kabupaten Semarang', 2017.

[3] H. P. H. Risya Istikhomah, 'Sistem Pendukung Keputusan Penyeleksian Calon Siswa Baru SMKN 2 Sragen dengan Metode Multifactor Evaluation Process (MFEP)', Artik. Tugas Akhir Progr. Stud. Sist. Informasi, Univ. Dian Nuswantoro (Udinus), Semarang, 2015.

[4] H. Pratiwi, 'Sistem Pendukung Keputusan Penentuan Karyawan Berprestasi Menggunakan Metode Multifactor’, J. SISFO Inspirasi Prof. Sist. Inf., vol. 5, no. 2, 2014. 
[5] Danik Kusumawardhani, 'Sistem Pendukung Keputusan Penerima Bantuan Rumah Layak Huni dengan menggunakan Metode Weighted Product (WP).', Progr. Stud. Tek. Inform. Fasilkom Univ. Dian Nuswantoro (Udinus), Semarang, 2014.

[6] D. M. Sri Wahyuni Priyanti, Indah Fitri AstutiKhairina, 'Penerapan Multifactor Evaluation Process (MFEP) untuk Pemilihan Kontraktor pada Proyek Semenisasi Jalan (Studi Kasus: Unit Layanan Pengadaan Kabupaten Kutai Kartanegara).', Pros. Semin. Sains dan Teknol. FMIPA, Univ. Mulawarman, Samarinda., 2016.

[7] Y. Maulana, 'Sistem Pendukung Keputusan Penyeleksian Bantuan Dana Rumah Tidak Layak Huni berbasis Web pada Kecamatan Kota Kudus dengan Metode Topsis.', Artik. Tugas Akhir Progr. Stud. Tek. Inform. Fasilkom Univ. Dian Nuswantoro (Udinus), Semarang, 2015.

[8] E. Natividade-Jesus, J. Coutinho-Rodrigues, and C. H. Antunes, 'A multicriteria Decision Support System for Housing Evaluation', Decis. Support Syst., 2007.

[9] M. A. Musen, B. Middleton, and R. A. Greenes, 'Clinical decision-support systems', in Biomedical Informatics: Computer Applications in Health Care and Biomedicine: Fourth Edition, 2014.

[10] R. Bogacz, 'Optimal decision-making theories', in Handbook of Reward and Decision Making, 2009.

[11] M. T. Ahmed and H. Omotunde, 'Theories And Strategies of Good Decision Making', Int. J. Sci. Technol. Res., 2012.

[12] O.-H. Negulescu, 'Using A Decision-Making Process Model In Strategic Management', 2014

[13] A. C. Kurtz dos Santos and J. Ogborn, 'A Model for Teaching and Reserch into Computacional Modelling’, J. Comput. Assist. Learn., 1992.

[14] A. Carmeli and J. H. Gittell, 'High Quality Relationships, Psychological Safety, and Learning from Failures in Work Organizations', J. Organ. Behav., 2009.

[15] S. Nidhra, 'Black Box and White Box Testing Techniques - A Literature Review', Int. J. Embed. Syst. Appl., 2012. 